\title{
Tasikmalaya Oktober Festival sebagai Pembuktian Destinasi Wisata Industri Kreatif dalam Memasarkan Produk Unggulan ke Mancanegara
}

\author{
Yani Sri Mulyani \\ Universitas Bina Sarana Informatika \\ E-Mail : yani.ymn@bsi.ac.id
}

\begin{abstract}
Tasikmalaya October Festival is an annual event held by the government of the city of Tasikmalaya in commemoration of the anniversary of the city of Tasikmalaya every October. The implementation of TOF itself is a joint event of major events which become an annual agenda in the City of Tasikmalaya. One of them is Tasik Halal Culinary Festival, Tasik Investment Expo \& Conference (TIEC), Tasikmalaya Culture \& Craft Festival, and Tasikmalaya Creative Festival (TCF). The activity was enlivened by the appearance of several special Tasikmalaya arts as well as the video profile screening of the City of Tasikmalaya which received a warm welcome from the ministry and all invitations present at the event. The Tasikmalaya city also became the pillar of industrial development for the regions in the eastern Priangan region. all of these potentials can be maximally utilized, especially in boosting the regional economy, there needs to be simultaneous and targeted promotion As is known, the City of Tasikmalaya has at least 4,500 small and medium scale creative industrial units, the creative industries in Tasikmalaya are not only embroidery, but also now batik is on the rise. The city of Tasikmalaya with all its capital and creative industry potential is indeed deserved to be encouraged so that it becomes the most advanced tourism city in East Priangan. The research method used is descriptive qualitative, analyzing only to the descriptive level, systematically analyzing and presenting facts so that it can be easier to be understood and concluded, as well as documentation and literature study, the results of the above research were concluded with the holding of the Tasik Oktober Festival to boost tourists to visit Tasikmalaya and had a positive impact on Tasikmalaya's economic activities.
\end{abstract}

Keywords: Tasik October Festival (TOF), creative industry,

Abstrak - Perhelatan Tasikmalaya October Festival merupakan event tahunan yang diselengarakan oleh pemerintah kota Tasikmalaya dalam rangka memperingati hari jadi kota Tasikmalaya setiap bulan oktober ..Pelaksanaan TOF sendiri merupakan ajang gabungan event-event besar yang menjadi agenda tahunan di Kota Tasikmalaya. Salah satunya adalah Tasik Halal Culinary Festival, Tasik Invesment Expo \& Conference (TIEC), Tasikmalaya Culture \& Craft Festival, serta Tasikmalaya Creative Festival (TCF). Kegiatan itu dimeriahkan oleh tampilan beberapa kesenian khas Tasikmalaya serta pemutaran video profil Kota Tasikmalaya yang mendapat sambutan hangat dari pihak kementerian dan seluruh undangan yang hadir dalam kegiatan tersebut.Kota Tasikmalaya pun menjadi penopang pembangunan industri bagi daerah-daerah yang berada di wilayah Priangan timur.Agar seluruh potensi tersebut bisa dimanfaatkan secara maksimal, terutama dalam mendongkrak perekonomian daerah, maka perlu ada promosi yang simultan dan tepat sasaran Seperti diketahui, Kota Tasikmalaya memiliki sedikitnya 4.500 unit industri kreatif berskala kecil menengah dan mikro,industri kreatif di Kota Tasikmalaya tidak hanya bordir, tapi juga batik yangsekarang tengah naik daun. Kota Tasikmalaya dengan segala modal dan potensi industri kreatifnya, memang pantas untuk terus didorong sehingga menjadi kota pariwisata termaju di Priangan Timur.. Metode penelitian yang digunakan yaitu deskriptif kualitatif,menganalisis hanya sampai pada taraf diskriptif,yaitu menganalisis dan menyajikan faktasecara sistematik sehingga dapat lebih mudah untuk dipahami dan disimpulkan ,serta dokumentasi dan studi pustaka,Hasil dari penelitian di atas disimpulkan dengan penyelenggaran Tasik Oktober Festival mendongkrak wisatawan untuk berkunjung ke Tasikmalaya dan berdampak positif bagi kegiatan perekonomian Tasikmalaya.

\section{Kata kunci : Tasik Oktober Festival (TOF), Industri kreatif}

\subsection{Latar Belakang}

Dunia pariwisata merupakan salah satu sektor penghasil devisa yang memiliki potensi cukup besarr untuk dikembangkan. Apabila sektor pariwisata dikembangkan dan dikelola dengan baik akan berdampak terhadap peningkatan kesejahteraan masyarakat, terutama sektor ekonomi riil yang ada di masyarakat. $\mathrm{Di}$ Indonesia, Industri kreatif sedang berkembang denga cepat, para ahli dan pakar ekonomi menyatakan bahwa pedapatan negara sebagian disumbang oleh industri kreatif yang terus bertumbuh dan berkembang pada setiap saat. 
Industri kreatif sendiri menurut Kementrian Perdagangan Indonesia adalah industri yang berasal dari pemanfaatan aktifitas, ketrampilan serta bakat individu untuk menciptakan kesejahteraan serta lapangan pekerjaan dengan menghasilkan dan mengekploitasi daya kreasi dan daya cipta individu tersebut.Industri kreatif saat ini memang memiliki peranan yang sangat penting pada perekonomian suatu negara, bukan hanya di negara berkembang seperti Indonesia. Hal ini tidak bisa dipisahkan karena industri kreatif memiliki peran meningkatkan perekonomian sebuah negara secara global. Industri kreatif erat hubunganya dengan tingkat kreativitas manusia sebagai sumber daya utama penggerak roda perekonomian. Banyaknya sektor industri kreatif yang tercipta adalah sebagai buah dari kreativitas dan inovasi yang dikembangkan oleh seseorang. Setiap tahunnya, perkembangan industri kreatif di Indonesia selalu bertambah dan berkembang. Dalam perjalananya Pemerintah Indonesia melalui Kementrian Pariwisata dan Ekonomi kreatif telah mengidentifikasi lingkup industri kreatif yang terdiri dari 15 sub sektor, berikut merupakan penjelasan dari sub sektor yang termasuk ke dalam industri kreatif.

Pentingnya kegiatan ini dilatarbelakangi bahwa Indonesia memiliki warisan budaya produk makanan khas, yang pada dasarnya merupakan sumber keunggulan komparatif bagi Indonesia. Hanya saja, kurangnya perhatian dan pengelolaan yang menarik, membuat keunggulan komparatif tersebut tidak tergali menjadi lebih bernilai ekonomis. Kegiatan ekonomi kreatif sebagai prakarsa dengan pola pemikir cost kecil tetapi memiliki pangsa pasar yang luas serta diminati masyarakat luas diantaranya usaha kuliner, assesoris, cetak sablon, bordir dan usaha rakyat kecil seperti penjual bala-bala, bakso, comro, gehu, batagor, bajigur dan ketoprak.

Kota Tasikmalaya adalah salah satu kota di Provinsi Jawa Barat yang dijuluki sebagai "Sang Mutiara dari Priangan Timur" dan dikenal juga sebagai "Kota Santri", khususnya di era sebelum 1980-an karena hampir di seluruh di wilayah ini tersebar pondok pesantren. Terletak di tenggara daerah Priangan, Kabupaten Tasikmalaya sejauh ini dinilai sebagai kabupaten paling besar dan berperan penting di wilayah Priangan Timur. Saat ini hampir $70 \%$, pusat bisnis, pusat perdagangan dan jasa, dan pusat industri di priangan timur dan selatan berada di Tasikmalaya. Sebagian besar wilayah Kabupaten Tasikmalaya merupakan daerah hijau, terutama pertanian dan kehutanan, sementara petani menetap sebagai mayoritas penduduk. Tasikmalaya juga terkenal dengan produksi kerajinannya, salak, dan sementara kuliner nasi tutug oncom. Beberapa tujuan wisata di Tasikmalaya di antaranya adalah Pantai Sindangkerta, Pemandian air panas Ciawi, Kampung Naga, Air terjun Ciparay, Gunung Galunggung, Pantai Selatan Cipatujah, Taman Mangkubumi Indah, Situ Gede, Goa Malawang, dan Curug Dengdeng.

Tasikmalaya October Festival yang merupakan ajang gabungan event besar yang menjadi agenda tahunan dengan menampilkan Tasik Halal Culinary Festival, Tasik Invesment Expo \& Conference (TIEC), Tasikmalaya Culture \& Craft Festival, serta Tasikmalaya Creative Festival (TCF) untuk menarik wisata lokal dan mancanegara.Gelaran karnaval budaya sukses menjadi sajian pembuka ajang Tasikmalaya October Festival (TOF), Antusiasme masyarakat yang begitu tinggi menyaksikan suguhan ragam seni budaya dan kerajinan khas lokal menandakan Tasikmalaya siap menjadi destinasi wisata berbasis industri kreatif. Dalam karnaval di suguhkan apa yang menjadi kekuatan Tasikmalaya sebagai kota industri kreatif. Dimana industri kreatif ini akan kita dorong menjadi pusat destinasi wisata produk kreatif di Jawa Barat selatan. Industri kreatif di Tasik memang sudah banyak dikenal. Diantaranya seperti Batik, Mendong, dan Bordir, termasuk Kelom Geulis dan Payung Geulis.

TOF tengah diupayakan menjadi pintu pembuka bagi Kota Tasikmalaya mengenalkan dan memasarkan produk-produk unggulannya termasuk tujuan wisata. Tasik Oktober Festival merupakan agenda rutin tahunan dan ikon Kota Tasikmalaya. Kegiatan tersebut menyambut hari jadi Kota Tasikmalaya dan merupakan gabungan dari beberapa acara yang telah digelar sebelumnya, yaitu Tasik Creative Festival, Tasikmalaya Culture and Craft Festival, dan Tasikmalaya Invesment Expo Conference. Penyelenggaraan TOF 2017 melibatkan para Usaha Kecil Menengah (UKM) produk kreatif unggulan (bordir, batik, kelom, payung, mendong bamboo, alas kaki dan makanan olahan), WUBI (Wirausaha Bank Indonesia), seniman dan pelaku budaya, Komunitas Kreatif Kota Tasikmalaya, serta Kadin Kota Tasikmalaya. Selain itu berpartisipasi Pemerintah Kota Baler, Filipina; Jerry Tan, Jaco Singapore Pte. Ltd., Singapura; MATTA, Malaysia; Palestine Indonesia Friendship Association (FIPA) dari Palestina; Gerd Wagner, Wagner $\mathrm{GmbH}$; dan Senior Expert Service (SES) dari Jerman; PA ASIA, Rio D Praaning dari Belgia. 


\subsection{Tinjauan Pustaka}

\subsubsection{Pariwisata}

Pengertian Pariwisata - Istilah "Pariwisata" sesungguhnya baru populer di Indonesia setelah diselenggarakannya Musyawarah Nasional Tourisme II di Tretes, Jawa Timur pada Tanggal 2-14 Juni 1958. Sebelumnya kata Pariwisata adalah Tourisme (dalam bahasa Belanda) yang kemudian sering diindonesiakan menjadi Tourisme (dalam Yoeti, 1996 : 112). Kata pariwisata berasal dari bahasa Sansekerta, yaitu yang terdiri dari 2 kata yakni pari dan wisata. Kata pari artinya: bersama atau berkeliling, sedangkan pada kata wisata artinya perjalanan. Jadi, pariwisata adalah yang melakukan suatu aktivitas perjalanan berkeliling dari satu tempat ke tempat lain yang menjadi objek tujuan wisata dengan sebuah perencanaan yang matang.

Menurut Yoeti (2003), Syarat suatu perjalanan disebut sebagai perjalanan pariwisata apabila (1) perjalanan dilakukan dari suatu tempat ke tempat yang lain, di luar tempatkediaman orang tersebut biasa tinggal; (2)Tujuan perjalanan semata mata untuk bersenang-senang dan tidak mencari nafkah di tenpat atau negara yang dikunjunginy; (3) Semata-mata sebagai konsumen di tempat yang .dikunjungi

Undang-undang Nomor 10 tahun 2009, menyebutkan pariwisata adalah segala sesuatu yang berhubungan dengan wisata, termasuk pengusahaan objek dan daya tarik wisata serta usaha-usaha yang berhubungan dengan penyelenggaraan pariwisata, dengan demikian pariwisata meliputi:

1. Semua kegiatan yang berhubungan dengan perjalanan wisata.

2. Pengusahaan objek dan daya tarik wisata seperti: kawasan wisata, Taman rekreasi, kawasan peninggalan sejarah, museum, pagelaran seni budaya, tata kehidupan masyarakat atau yang bersifat alamiah: keindahan alam, gunung berapi, danau, pantai.

3. Pengusahaan jasa dan sarana pariwisata yaitu: usaha jasa pariwisata (biro perjalanan wisata, agen perjalanan wisata, konvensi, perjalanan insentif dan pameran, konsultan pariwisata, informasi pariwisata). Usaha sarana pariwisata yang terdiri dari akomodasi, rumah makan, bar, angkutan wisata.

\subsubsection{Wisatawan}

Wisatawan merupakan bagian yang tak terpisahkan dari dunia pariwisata. Wisatawan sangat beragam, tua-muda, miskin-kaya, asing-nusantara, semuanya mempunyai keinginan dan juga harapan yang berbeda.
Jika ditinjau dari arti kata "wisatawan" yang berasal dari kata "wisata" maka sebenarnya tidaklah tepat sebagai pengganti kata "tourist" dalam bahasa Inggris. Kata itu berasal dari bahasa Sansekerta "wisata" yang berarti "perjalanan" yang sama atau dapat disamakan dengan kata "travel" dalam bahasa Inggris. Jadi orang melakukan perjalanan dalam pengertian ini, maka wisatawan sama artinya dengan kata "traveler" karena dalam bahasa Indonesia sudah merupakan kelaziman memakai akhiran "wan" untuk menyatakan orang dengan profesinya, keahliannya, keadaannya jabatannya dan kedudukan seseorang (Irawan, 2010:12)

Wisatawan adalah orang-orang yang melakukan kegiatan wisata (Undang-undang nomor 10 tahun 2009). Jadi menurut pengertian ini, semua orang yang melakukan perjalanan wisata dinamakan wisatawan. Apapun tujuannya yang penting, perjalanan itu bukan untuk menetap dan tidak untuk mencari nafkah ditempat yang dikunjungi. Wisatawan yang berkunjung ke suatu daerah biasanya benar-benar ingin menghabiskan waktunya untuk bersantai, menyegarkan fikiran dan benar-benar ingin melepaskan diri dari rutinitas kehidupan sehari-hari. Jadi bisa juga dikatakan wisatawan adalah seseorang yang melakukan perjalanan dari suatu tempat lain yang yang jauh dari rumahnya bukan dengan alasan rumah atau kantor (Kusumaningrum, 2009: 17).

\subsubsection{Pengertian Industri}

Pengertian Industri menurut UU No.5 tahun 1984 tentang Perindustrian, industri adalah kegiatan ekonomi yang mengolah bahan mentah, bahan baku, brang setengah jadi, dan/atau barang jadi menjadi barang nilai yang tinggi untuk penggunaannya, termasuk kegiatan rancang bangun dan perekayasaan industri. Sedangkan (Pramudi 2006:4) mendefinisikan industri adalah bagian dari sebuah porses yang mengolah bahan mentah menjadi barang jadi sehingga menjadi sebuah barang yang baru yang memiliki nilai lebih tinggi bagi kebutuhan masyarakat .

\subsubsection{Industri Kreatif}

Ekonomi kreatif atau industri kreatif atau disebut juga dengan istilah knowledge based economy adalah pendekatan, tren, konsep dan kegiatan ekonomi yang bersumber dari kreativitas, inovasi, bakat, ide dan gagasan serta mengandalkan sumber daya manusia sebagai faktor produksi untuk menjalankan ekonomi. Pertumbuhan ekonomi kreatif digerakkan oleh kapitalis kreativitas dan inovasi dalam menghasilkan produk atau jasa dengan kandungan kreatif. Ekonomi kreatif adalah sistem kegiatan manusia yang berkaitan dengan kreasi, produksi, distribusi, 
pertukaran dan konsumsi barang dan jasa yang bernilai bagi para pelanggan pasar. Berikut ini beberapa definisi dan pengertian ekonomi kreatif atau industri kreatif dari beberapa sumber buku:

Menurut Departemen Perdagangan Republik Indonesia (2008), industri kreatif adalah industri yang berasal dari pemanfaatan kreativitas, ketrampilan, serta bakat individu untuk menciptakan kesejahteraan serta lapangan pekerjaan melalui penciptaan dan pemanfaatan daya kreasi dan daya cipta individu tersebut. Menurut Simatupang (2007), industri kreatif adalah industri yang berfokus pada kreasi dan eksploitasi karya kepemilikan intelektual seperti seni, film, permainan atau desain fashion, dan termasuk layanan kreatif antar perusahaan seperti iklan.

Menurut Institute For Development Economy and Finance (2005), ekonomi kreatif merupakan proses peningkatan nilai tambah hasil dari eksploitasi kekayaan intelektual berupa kreativitas, keahlihan, dan bakat individu menjadi sautu produk yang dapat dijual. Menurut Howkins (2001), ekonomi Kreatif terdiri dari periklanan, arsitektur, seni, kerajinan. desain, fashion, film, musik, seni pertunjukkan, penerbitan, penelitian dan pengembangan (R\&D), perangkat lunak, mainan dan permainan, televisi dan radio, dan permainan video.

\subsubsection{Ciri-ciri Ekonomi Kreatif}

Ekonomi kreatif atau industri kreatif memiliki ciri khusus, yaitu menampilkan keunggulan kreativitas dalam menghasilkan desain-desain kreatif yang melekat pada produk barang/jasa yang dihasilkan. Ekonomi Kreatif merupakan pengembangan ekonomi berdasarkan pada keterampilan, kreativitas dan bakat individu untuk menciptakan daya kreasi dan daya cipta individu yang bernilai ekonomis, sehingga menitikberatkan pada pengembangan ide dalam menghasilkan nilai tambahan.

Ekonomi kreatif atau industri kreatif memiliki ciri-ciri sebagai berikut: Memiliki unsur utama kreativitas, keahlian dan talenta yang berpotensi meningkatkan kesejahteraan melalui penawaran kreasi intelektual. Terdiri dari penyediaan produk kreatif langsung kepada pelanggan dan pendukung penciptaan nilai kreatif pada sektor lain yang secara tidak langsung berhubungan dengan pelanggan. Siklus hidup singkat, margin tinggi, keanekaragaman tinggi, persaingan tinggi, dan mudah ditiru.

Dalam buku Pengembangan Industri Kreatif 2025, Departemen Perdagangan Republik Indonesia (2008), jenis ekonomi kreatif dibagi menjadi 15 sektor industri atau ekonomi kreatif, yaitu:

1. Periklanan (Advertising)

Sub sektor induatri kreatif yang pertama adalah advertising atau dunia periklanan. Advertisisng mencakup segala bentuk industri kreatif yang bergerak dibidang jasa periklanan atau biasa juga disebut kmunikasi satu arah dengan menggunakan medium tertentu. Kegiatan ini meliputi proses kreasi atau pembuatan ide, operasi, dan distribusi dari periklanan yang dihasilkan, misalnya riset pasar, perencanaan komunikasi periklanan, media periklanan luar ruang, produksi material periklanan, promosi dan kampanye relasi publik. Selain itu, advertising juga mecakup tampilan periklanan di media cetak (surat kabar dan majalah) dan elektronik (televisi dan radio), pemasangan berbagai poster serta gambar, penyebaran selebaran, pamflet, edaran, brosur dan media reklame sejenis lainnya, distribusi serta penyewaan kolom untuk iklan.

2. Arsitektur

Sub sektor industri kreatif selnjutnya adalah arsitektur, arsitektur sendiri adalah kegiatan kreatif yang berkaitan dengan desain bangunan secara menyeluruh, baik dari level makro (town planning, urban design, landscape architecture) sampai level mikro (detail konstruksi). Misalnya sebagai contoh industri ini bergerak dengan projek projek seperti bangunan warisan sejarah, pengawasan konstruksi, perencanaan kota, konsultasi kegiatan teknik dan rekayasa seperti bangunan sipil dan rekayasa mekanika dan elektrikal.

3. Pasar Barang Seni

Sub sektor industri kreatif ketiga adalah pasar barang dan seni. Kegiatan kreatif yang berkaitan dengan perdagangan barang-barang asli khas suatu daerah, handmade, unik dan langka serta memiliki nilai estetika seni dan sejarah yang tinggi melalui media lelang, galeri, toko, pasar swalayan dan juga online melalui internet, prodk dari industri ini biasanya berupa barang-barang musik, percetakan, kerajinan, automobile, dan film.

4. Kerajinan (Craft)

Sub sektor seni selanjutnya adalah kerajinan atau juga biasa disebut craft. Craft adalah kegiatan kreatif yang berkaitan dengan kreasi pembuatan, produksi dan distribusi produk yang dibuat atau dihasilkan oleh tenaga pengrajin yang berawal dari desain awal sampai proses penyelesaian produknya langsung dari 
tangan pengrajin. Hasil dari produk-produk kerajinan berupa barang kerajinan yang terbuat dari batu berharga, serat alam maupun buatan, kulit, rotan, bambu, kayu, logam (emas, perak, tembaga, perunggu dan besi), kaca, porselen, kain, marmer, tanah liat, dan kapur. Produk kerajinan pada umumnya hanya diproduksi dalam jumlah yang relatif kecil (Limited edition).

5. Desain

Sub sektor seni yang kelima adalah desain, Desain adalah kegiatan kreatif yang terkait dengan kreasi menggunkan desain grafis, desain interior, desain produk, desain industri, konsultasi identitas perusahaan dan jasa riset pemasaran serta produksi kemasan dan jasa pengepakan.

6. Industri Pakaian (Fashion)

Sub sektor keenam adalah industri pakaian, kegiatan kreatif fashion yang terkait dengan kreasi desain pakaian, desain alas kaki, dan desain aksesoris mode lainnya, produksi pakaian mode dan aksesorisnya, konsultasi lini produk berikut distribusi produk fesyen. Pada dewasa ini Indonesia kebanjira industri kreatif dibidang fashion muslim yang berkembang sangat pesat dan memunculkan namanama baru yang tentu saja berbakat.

7. Video, Film dan Fotografi

Sub sektor selanjutnya adalah industri video, film, dan fotografi, sama halya dengan industri fashion yang berkembang pesat Kegiatan kreatif yang terkait dengan kreasi produksi video, film, dan jasa fotografi, serta distribusi rekaman video dan film sedang mengalami masa pertumbuhan yang terbilang cukup pesat juga. Termasuk di dalamnya penulisan skrip, dubbing film, sinematografi, sinetron, dan eksibisi atau festival film.

8. Permainan Interaktif (Game)

Sub sektor selanjutnya adalah industri game. Kegiatan kreatif yang berkaitan dengan kreasi, produksi, dan distribusi permainan komputer dan video yang bersifat hiburan, ketangkasan, dan edukasi. Sub-sektor permainan interaktif bukan didominasi sebagai hiburan semata-mata tetapi juga sebagai alat bantu pembelajaran atau edukasi.

9. Musik

Sub sektor selanjutnya adalah industri musik. Kegiatan kreatif yang berkaitan dengan kreasi atau komposisi, pertunjukkan, reproduksi, dan distribusi dari rekaman suara. Meski industri ini sempat meredu terhalang oleh issue pembajakan kini pegiat seni musik menggunakan media pembelian lagu di internet menggatikan besntuk fisik sebuah album

10. Seni Pertunjukan (Showbiz)

Sub sektor kesepuluh dalah industri pertunjukan. Kegiatan kreatif yang berkaitan dengan usaha pengembangan konten, produksi pertunjukkan. Misalnya, pertunjukkan wayang, balet, tarian tradisional, tarian kontemporer, drama, musik tradisional, musik teater, opera, termasuk musik etnik, desain dan pembuatan busana pertunjukkan, tata panggung, dan tata pencahayaan.

11. Penerbitan dan Percetakan

Sub sektor kesebelas adalah industri penerbitan dan percetakan.Kegiatan kreatif yang terkait dengan penulisan konten dan penerbitan buku, jurnal, koran, majalah, tabloid, dan konten digital serta kegiatan kantor berita dan pencari berita. Subsektor ini juga mencakup penerbitan perangko, materai, uang kertas, blanko cek, giro, surat andil, obligasi, saham dan surat berharga lainnya, paspor, tiket pesawat terbang, dan terbitan khusus lainnya. Juga mencakup penerbitan fotofoto, grafir (engraving) dan kartu pos, formulir, poster, reproduksi, percetakan lukisan, dan barang cetakan lainnya, termasuk rekaman mikro film.

12. Layanan Komputer dan Piranti Lunak (Software)

Sub sektor selanjutnya adalah industri komputer dan perangkat lunak. Kegiatan kreatif yang terkait dengan pengembangan teknologi informasi, termasuk layanan jasa komputer, pengolahan data, pengembangan database, pengembangan piranti lunak, integrasi sistem, desain dan analisis sistem, desain arsitektur piranti lunak, desain prasarana piranti lunak dan piranti keras, serta desain portal termasuk perawatannya.

13. Televisi \& Radio (Broadcasting)

Sub sektor ke tigabelas adalah industri pertelvisian. Kegiatan kreatif yang berkaitan dengan usaha kreasi, produksi dan pengemasan acara televisi (seperti games, kuis, reality show, infotainment, dan lainnya), penyiaran, dan transmisi konten acara televisi dan radio, termasuk kegiatan station relay (pemancar) siaran radio dan televisi.

14. Riset dan Pengembangan (R\&D)

Sub sektor selanjutnya adalah industri riset dan pengembangan. Kegiatan kreatif terkait dengan usaha inovatif yang menawarkan penemuan ilmu dan teknologi, serta mengambil manfaat terapan dari ilmu dan teknologi tersebut guna perbaikan 
produk dan kreasi produk baru, proses baru, material baru, alat baru, metode baru, dan teknologi baru yang dapat memenuhi kebutuhan pasar. Termasuk yang berkaitan dengan humaniora, seperti penelitian dan pengembangan bahasa, sastra, dan seni serta jasa konsultansi bisnis dan manajemen.

15. Kuliner

Sub sektor terakhir adalah industri kuliner. Industri kuliner kian menggeliat di Indonesia. Data dari Badan Ekonomi Kreatif (Bekraf) Republik Indonesia mencatat, subsektor kuliner berkontribusi 41,4 persen dari total kontribusi perekonomian kreatif $\mathrm{Rp} 922$ triliun pada 2016. Jumlah tersebut merupakan yang paling tinggi dibandingkan 16 subsektor lain di Bekraf RI. "Kuliner merupakan salah satu penopang di industri kreatif. Dari unit 8,2 juta unit industri kreatif, 68 persen bergerak di industri kuliner. Sub sektor kuliner memberikan kontribusi yang cukup besar, yaitu $30 \%$ dari total pendapatan sektor pariwisata dan ekonomi kreatif. Industri kuliner mempunyai potensi yang sangat kuat untuk berkembang, oleh karena itu pemerintah akan mendukung sub sektor ini supaya lebih maju.

\subsection{Metode Penelitian}

Metode penelitian yang digunakan yaitu deskriptif kualitatif,menganalisis hanya sampai pada taraf diskriptif, yaitu menganalisis dan menyajikan faktasecara sistematik sehingga dapat lebih mudah untuk dipahami dan disimpulkan. (Azwar,2010:6).Me njelaskan atau mendiskripsikan variabel penelitian tanpa mencari jalinan hubungan antara variabel yang satu dengan variabel yang lainnya. Artinya penelitia ini hanya sebatas pada usaha mengungkapkan masalah dan keadaan sebagaimana adanya sehingga hanya berupa penyingkapan fakta. Selain itu dokumentasi dan studi pustaka diambil dalam penelitian tersebut diatas.

\subsection{Hasil dan Pembahasan \\ 4.1.1. Produk-produk Unggulan Tasikmalaya \\ Kota}

Salah satu merek dagang Tasikmalaya adalah kerajinan tangan seperti Kerajinan Bambu, Payung Geulis, Bordir, Batik, Mendong Plait, Kelom Geulis, Kerajinan Kayu dan Makanan Tradisional yang dibuat dengan penuh cinta dan kebahagiaan. Payung Geulis sendiri telah menjadi ikon Kota Tasikmalaya. Jadi sudah waktunya untuk merasakan dan menikmati seni dan budaya Tasikmalaya.

\section{Payung Geulis}

Payung Geulis merupakan ikon dari Kota Tasikmalaya yang keberadaannya hampir punah.Pada masa penjajahan Belanda sekitar tahun 1926 dipakai oleh nonenone Belanda. Payung geulis yang terbuat dari bahan kertas dan kain mengalami masa kejayaan pada era 1955 sampai 1968. Namun masa kejayaan itu berangsur-angsur surut setelah pemerintah pada tahun 1968 menganut politik ekonomi terbuka. Sehingga payung buatan pabrikan dari luar negeri masuk ke Indonesia. Hal ini berdampak pada hancurnya usaha kerajinan payung geulis di Tasikmalaya. Usaha kerajinan ini mulai bersinar kembali sejak tahun 1980-an. Para perajin mulai membuka kembali usaha pembuatan payungwalau dalam jumlah kecil. Payung merupakan alat pelindung dari hujan dan panas sedangkan Geulis memiliki arti elok atau molek sehingga Payung Geulis memiliki arti payung cantik yang bernilai estetis. Terdapat dua motif payung geulis yaitu motif hias geometris berbentuk bangunan yang lebih menonjol seperti garis lurus, lengkung dan patah-patah, dan motif hias non geometris diambil dari bentuk alam seperti manusia, hewan dan tanaman.Payung geulis ini rangkanya terbuat dari bambu. Setelah dirangkai dan dipasangi kain dan kertas, ujung payung dirapikan dengan menggunakan kanji. Agar menarik, rangka bagian dalam diberi benang warna-warni. Proses pembuatan payung ini bergantung pada sinar matahari, karena setelah diberi kanji, payung dijemur hingga keras. Payung kemudian diberi warna, serta dilukis dengan corak bunga. Semua proses pembuatan payung geulis dibuat secara manual dengan buatan tangan/handmade kecuali gagang payung dibuat dengan menggunakan mesin.

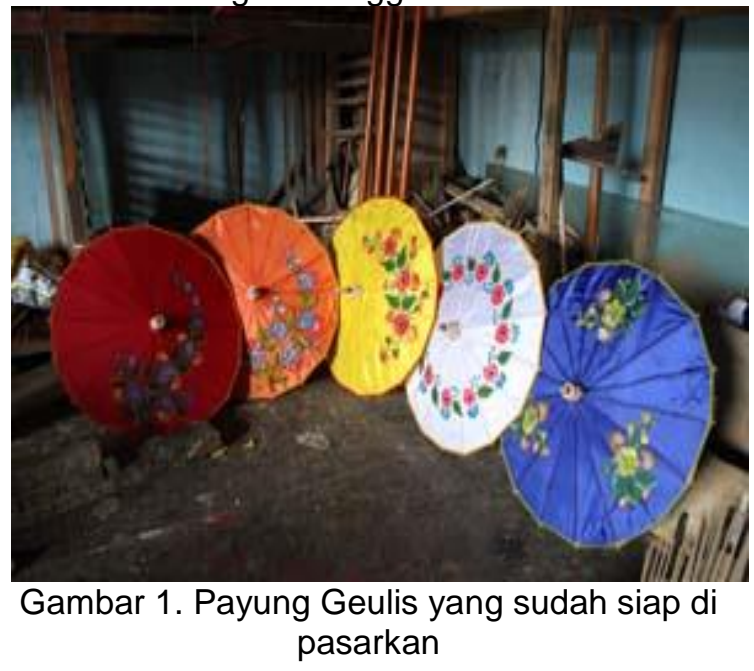


Terhambatnya perkembangan usaha perajin payung karena perajin belum mau melakukan inovasi dan kreativitas produk dan masih tetap mempertahankan model dan motiflama;Para generasi muda enggan menekuni kerajinan membuat payung ini karena upahnya sangat kecil, membutuhkan ketelitian dan kesabaran dalam proses pembuatannya dan payung hanya dibuat berdasarkan pesanan; Pemasaran payung geulis masih terbatas; dan modal kerja yang masih terbatas.

2. Kelom Geulis

Kelom Geulis diambil dari bahasa Belanda yaitu 'kelompen' yang artinya sandal kayu. Istilah Kelom Geulis Tasikmalaya sendiri berasal dari bahasa sunda yang berarti sandal kayu cantik. Sandal kelom biasanya di pakai untuk acara hajatan ataupun acara resmi.Kelom Geulis Tasikmalaya terbuat dari kayu mahoni atau albasia. Kelom Geulis ini di buat secara manual dengan menggunakan tangan. Agar tampak menarik, kelom di berikan hiasan. Hiasan kelom umumnya adalah hiasan ukiran dengan motif bunga. Sekarang ini, terdapat juga kelom dengan menggunakan hiasan cat air brush dan juga hiasan batik atau yang lebih di kenal dengan kelom batik.

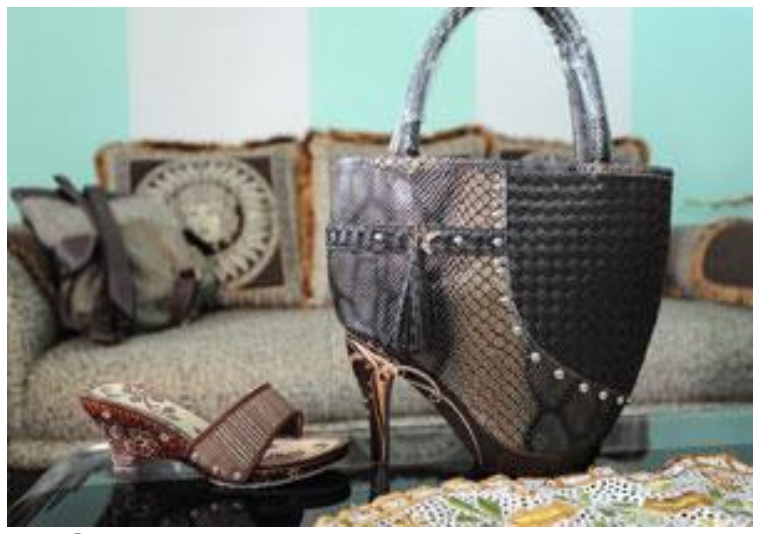

Gambar 2. Berbagai jenis Kelom geulis

Salah satu produk andalan Kota Tasikmalaya ini banyak di produksi sebagai Home Industri. Sentra produksi kerajinan Kelom Geulis Tasikmalaya terdapat di Desa Setiamulya, Mulyasari, Kersanegara, Sukahurip, Sumelap.

3. Kerajinan Kayu

Produk unggulan lainnya dari kota Tasikmalaya adalah kerajinan kayu diantaranya boneka kayu. Salah satu pengrajin boneka kayu di Kota Tasikmalaya ini adalah Ade Suherman pemilik CV. Atlas Duta Kriya. Beberapa boneka lucu mulai dari boneka buahbuahan, sayuran, ondel-ondel dan boneka
Jepang dihasilkan oleh Ade. Untuk bahan dasarnya menggunakan kayu yang memang sudah tidak terpakai atau bisa dibilang sebagai limbah. Untuk memesan boneka-boneka kayu ini dapat dipesan ke alamat Jalan Leuwi Anyar No. 123 Tasikmalaya, Telp. 081320457767.

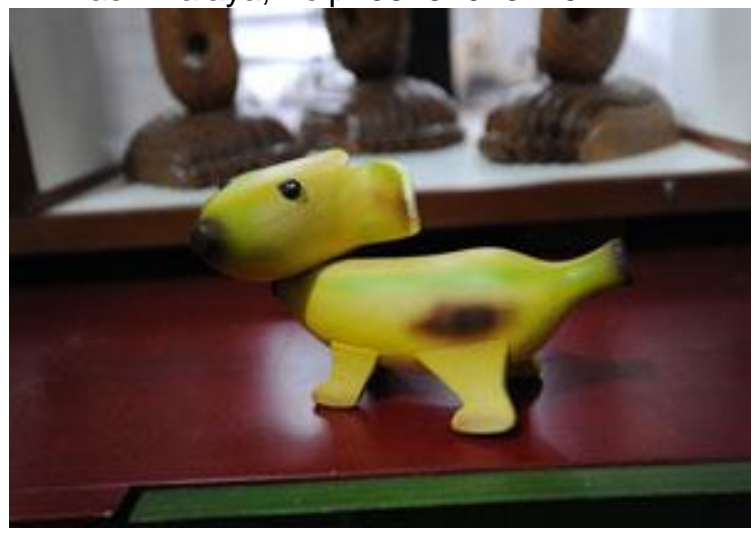

Gambar 3. Kerajinan Binatang kayu

4. Kerajinan Mendong

Kerajinan mendong sudah sangat terkenal berasal dari Tasikmalaya. Mulai dari tikar, tempat pinsil, dompet, tempat sampah, tempat toples, tas, dan lainnya banyak dihasilkan para pengrajin mendong. Sentra pengrajin mendong di kota Tasikmalaya ada di daerah kecamatan Purbaratu. Di daerah ini ada sekitar 100 pengrajin mending.

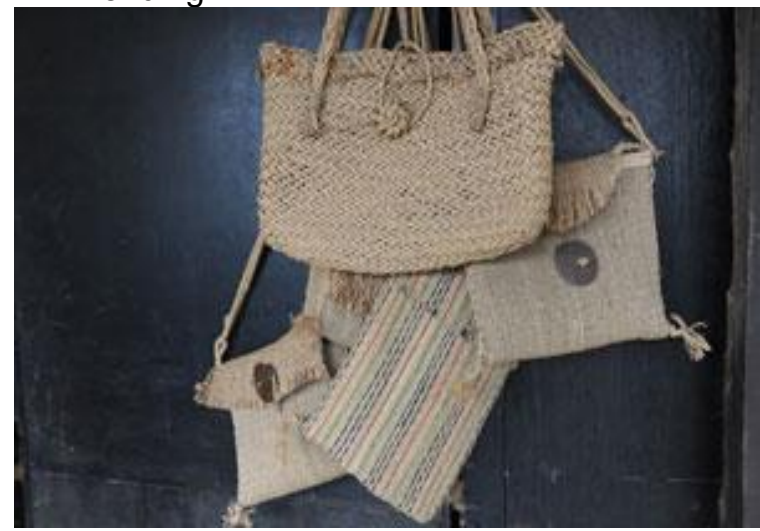

Gambar 4. Kerajian Tas dari bahan mendong $\mathrm{H}$. Abdul Latief, salah seorang pengrajin mendong dengan nama "AL-SINKTA" yang beralamat di Purbaratu No. 45 Tasikmalayabiasa memproduksi mulai daritikar, tempat pinsil, dompet, tempat sampah, tempat toples, tas, dan lainnya.

\subsubsection{Tasikmalaya Oktober Festival sebagai Pembuktian Destinasi Wisata Industri Kreatif}

Tasik Oktober Festival merupakan ajang promosi produk-produk unggulan Tasikmalaya seperti batik, payung geulis, ayaman mendong, kelom geulis, anyaman bambu serta berbagai makanan olahan lainnya. Pembukaan Tasik oktober festival 
yang selalu dihadiri langsung dan dibuka oleh menteri pariwisatan Arief Yahya ,hal ini sangat tepat bagi pemerintahan dan masyarakat Tasikmalaya untuk dijadikan ajang promosi produk unggulan Tasikmalaya, yang dalam hal ini banyak tamu dari luar negeri yang menghadiri serta berkunjung ke Tasik oktober Festival diantaranya dari Singapura, Malasyia,Jepang , palestina ,Jerman dan lainnya.

Selain diadakannya Stand-stand dagang hasil dari produk unggulan Tasikmalaya di sepanjang H.Z Mustofa. Tasik oktober festival jugan menyelenggrakan Carnaval Budaya dan Fashion Carnaval di sepanjang jalan Otto Iskandardinata.

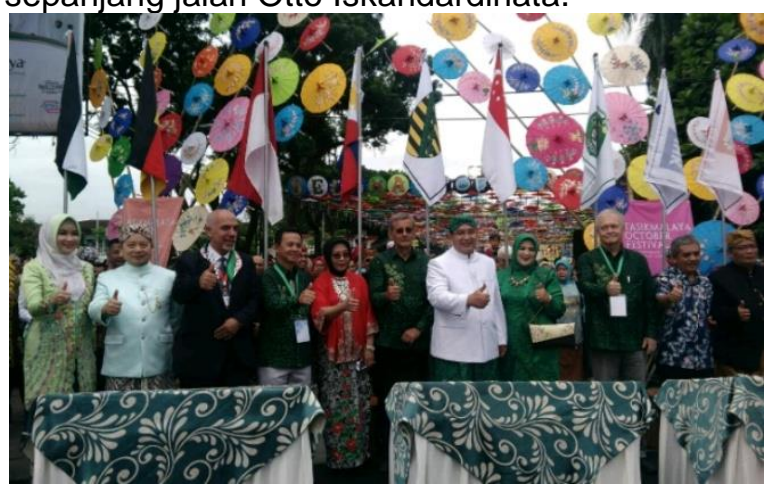

Gambar 5. Pembukaan Tasikmalaya Oktober Festival

Pembukaan Tasik oktober festival oleh Walikota Tasikmalaya H.Budi Budiman dan dihadiri Bapak menteri Pariwisata serta para tamu undangan dari luar negeri.

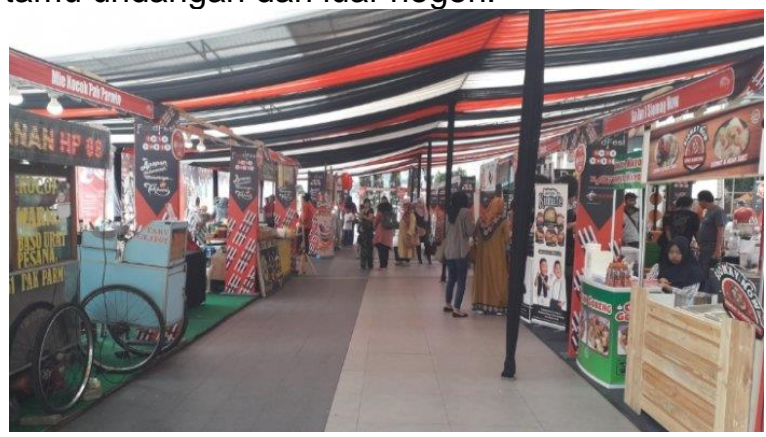

Gambar 6. Pameran Serta Stand-Stand

Unggulan Produk Unggulan Tasikmalaya Stand utama dari tugu adipura sampai perempatan cihideung itu dari binaan Diskoperindag dimana terdiri 142 stand. dan Dari perempatan cihideung sampai perempatan pataruman itu dari $\mathrm{BI}$ jumlahnya 60 stand sedangkan Dari perempatan pataruman dampai panyerutan itu oleh indag untuk food dan kuliner jumlahnya 40 stand yang diisi oleh 80 peserta dengan tambahan tenda dan tempat mandiri untuk menampung peserta yang tidak tertampung.Peserta ada dari luar kota untuk makanan dan minuman saya rasa itu tidak jadi masalah, sementara untuk peserta food dan Kuliner itu Ada binaan
$\mathrm{BI}$ dipengolahan makanan dari wubi, piwk yang menempati stand tsb.

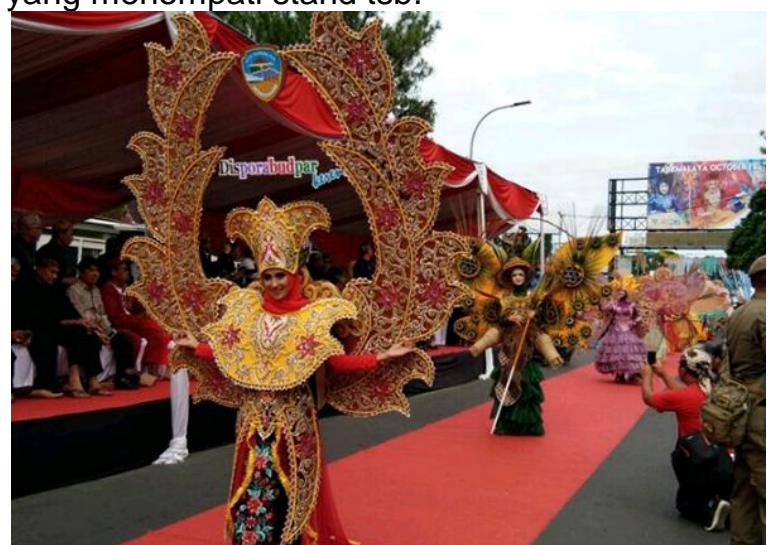

Gambar 7.Lomba fashion Karnaval

Fashion karnaval dan karnaval budaya yang diikuti oleh berbagai instansi pemerintahan serta perguruan yang ada di kota Tasikmalaya.

Dengan diadakannya penyelenggaraan Tasik Oktober Festival mendongkrak kunjungan wisatawan ke Tasikmalaya yg mana berdanpak positif bagi perekonomian di Tasikmalaya dan menjadi ajang promosi untuk memasarkan produk Industri kreatif ke luar kota Tasikmalaya maupun ke mancanagara.Seperti yang terlihat di tabel di bawah ini

KUNJUNGAN WISATAWAN

KE KOTA TASIKMALAYA

\begin{tabular}{|r|c|c|c|}
\hline NO & TAHUN & JMLH WISATAWAN & KET \\
\hline 1 & 2014 & 19915 & \\
\hline 2 & 2015 & 22133 & \\
\hline 3 & 2016 & 22800 & \\
\hline 4 & 2017 & 23700 & \\
\hline 5 & SEP'2018 & 19497 & \\
\hline
\end{tabular} $\begin{aligned} & \text { Sumber dari } \\
& \text { Tasikmalaya }\end{aligned}$

\subsection{Kesimpulan}

Kegiatan yang juga merupakan rangkaian peringatan HUT kota Tasikmalaya ini diselenggarakan oleh Dina Kepariwisataan idan Olahraga Kota Tasikmalaya TOF terdiri dari beberapa rangkain acara, antara lain Tasik Creative Festival, Tasikmalaya Culture and Craft Festival dan Tasikmalaya Invesment Expo Conference.Selain sebagai acara peringatan hari jadi kota Tasikmalaya, TOF bertujuan sebagai ajang untuk memperkenalkan kebudayaan, tradisi, wisata dan produk-produk unggulan asli kota Tasikmalaya. Acara TOF ini sukses menarik banyak wisatawan dalam negeri, delegasi dan bahkan wisatawan asing /manca negara. Perhelatan Tasikmalaya October Festival (TOF) Diharapkan kegiatan tersebut 
mampu mendongkrak daya saing usaha di kota santri tersebut,terutama dibidang industri jasa dan perdagangan. Dengan adanya penyelenggaraan Tasik Oktober Festival meningkatnya wisatawan yang berkunjung ke Tasikmalaya sehingga membawa dampak positif bagi industri yang ada di Tasikmalaya dan hal ini mendongrak pemasaran industri kreatif yag ada di Tasikmalaya.

\section{Daftar Pustaka}

[1] Azwar, Saifudin.2010 Metode Penelitian Yogyakarta: Pustaka Pelajar.

[2] Departemen Perdagangan Republik Indonesia. 2008. Pengembangan Ekonomi Kreatif Indonesia 2025. Jakarta: Depdag RI.

[3] Howkins, J.2001. The Creative Economy: How People Make Money from Ideas. London: Penguins Books.

[4] Irawan, Koko. 2010. Ilmu Pariwisata Sebuah Pengantar Perdana ,Pt Pradnya,Jakarta.

[5] Kusumaningrum. 2009, Ekonomi Pariwisata. Gramedia Pustaka Utama, Jakarta

[6] Marpaung, Happy. 2002.

Pengetahuan Kepariwisataan Edisi

Revisi. Bandung : Alfabeta
[7] Pramudia, Teguh S. 2006. Perjalanan si Konsep Seksi ,SWA Sembada. No 26/XIII/19 Desember 2005-11 Januari 2006. Sajian Utama. Hal 46-50

[8] Simatupang, Togar. 2007. Ekonomi Kreatif: Menuju Era Kompetisi dan Persaingan Usaha Ekonomi Gelombang IV. Bandung: ITB

[9] Yoeti, Oka A. 2008 .Perencanaan dan Pengembangan Pariwisata Jakarta : Pt. Pradaya Pramta,

[10] Yoeti, Oka A. 2003 Pemasaran Pariwisata, Bandung : PT Angkasa

Sumber lain:

[11]Undang-Undang Republik Indonesia nomor 10 Tahun 2009, Kepariwisataan, Jakarta 2009.

[12] http://jabarprov.go.id/index.php/potensi_d aerahdetail/133/1

[13] https://travel.kompas.com/read/2018/02/06 /185000027/industri-kulinerpenopangtertinggiperekonomian-kreatif-diindonesia

[14] http://www.bekraf.go.id/subsektor/page/kuli ner 